\title{
NAUKA PRAWA OCHRONY ŚRODOWISKA W POLSCE
}

\section{LEGAL STUDIES ON ENVIRONMENTAL LAW IN POLAND}

\author{
http://dx.doi.org/10.12775/PPOS.2014.040
}

\section{STRESZCZENIE}

Przedstawiany artykuł jest rozszerzoną i udokumentowaną przypisami wersją wykładu wygłoszonego przez autora 16 czerwca 2014 r. na Uniwersytecie Śląskim w Katowicach przy okazji nadania mu doktoratu honoris causa. Autor zaproponował słuchaczom i proponuje czytelnikom towarzyszenie mu w wycieczce po podstawowych ośrodkach naukowych zajmujących się prawem ochrony środowiska w Polsce, z zachodu na wschód i z północy na południe, od Szczecina poczynając, a na Rzeszowie kończąc.

" Prof. dr hab., doktor honoris causa Uniwersytetu Śląskiego, Instytut Nauk Prawnych Polskiej Akademii Nauk. 


\section{Słowa kluczowe}

Przyroda; środowisko; prawo środowiska; nauka prawa środowiska; ośrodek naukowy; podręcznik; komentarz.

\section{ABSTRACT}

This paper is an enlarged and supported by footnotes version of the lecture delivered by the author on 16 June 2014 at the Silesian University in Katowice on the occasion of conferring upon him the degree of Doctor honoris causa. The author invites his listeners and readers to accompany him on a trip through academic centres for environmental law in Poland, from west to east and from north to south, starting in Szczecin and finishing in Rzeszow.

\section{Keywords}

Nature; environment; environmental law; legal studies on the environmental law; academic centre; manual; commentary.

\section{WPROWADZENIE}

Pozwalam sobie zaproponować Czytelnikom wycieczkę po głównych ośrodkach naukowych zajmujących się prawem ochrony środowiska (prawem środowiska) w Polsce. Zaczniemy w Szczecinie i kierując się na wschód trzema pasami: północnym, środkowym i południowym, zakończymy w Rzeszowie, napotykając po drodze na ośrodki naukowe i przedstawicieli nauki w nich działających. Naszą wycieczkę poprzedzimy wspomnieniem o tych uczonych, których już wśród nas nie ma. Zastrzegam od razu, że nie jestem w stanie (także ze względu na ograniczone ramy artykułu kierowanego do czasopisma) wymienić wszystkich zasłużonych dla nauki prawa ochrony środowiska wczoraj i dziś, tym bardziej nie jestem w stanie wymieć wszystkich znaczących dzieł z zakresu nauki prawa ochrony środowiska. Przedstawiany materiał ma charakter czysto subiektywny, wręcz osobisty; dokonuję trudnych wyborów, za które ponoszę pełną odpowiedzialność. Pisząc 4/2014 o autorach, świadomie i celowo pomijam stopnie i tytuły na- 
ukowe; autorka bądź autor występują u mnie w tym opracowaniu tylko pod imieniem i nazwiskiem.

\section{CHWILA WSPOMNIEŃ}

Przed wyruszeniem w drogę przypomnę najbardziej znaczące postacie z dziedziny nauki o prawie ochrony przyrody i środowiska, zaczynając od Jana Gwalberta Pawlikowskiego (1860-1939), prawnika, ekonomisty, literaturoznawcy, wielkiego formatu działacza i ideologa ochrony przyrody. Jego autorstwa jest płomienny manifest ${ }^{1}$ zarysowujący idee ochrony przyrody, od strony prawnej zaś najistotniejsze znaczenie ma jego podstawowe dzieło ${ }^{2}$ tworzące podstawy teorii prawa ochrony przyrody, które ze względu na głęboko przemyślane konstrukcje zachowuje aktualność do dziś. Z okresu międzywojennego przypomnieć jeszcze trzeba Jana Juliana Nowaka i jego koncepcję ochrony przyrody jako służby publicznej ${ }^{3}$.

Przechodząc do czasów, które już sam pamiętam, zacznę od trzech „ojców założycieli” teorii prawa ochrony środowiska. Główne dzieło pierwszego z nich, Wacława Brzezińskiego ${ }^{4}$, nadal wytycza sposób rozumienia pojęcia środowiska, a zwłaszcza dodawanego do niego przymiotnika „naturalne” oraz przedstawia w ujęciu koncepcyjnym najważniejsze instrumenty prawnej ochrony środowiska. Podstawową zasługą drugiego, Leona Łustacza, było przygotowanie pierwszej dużej konferencji polskich prawników przystępujących do badań nad ochroną środowiska w 1971 r. oraz zredagowanie zbioru wystąpień na tej konferencji $^{5}$, a także zebranie kilkunastu prawników, ekonomistów i socjologów, którzy wspólnie przygotowali jedną z ważniejszych

1 J. G. Pawlikowski, Kultura a natura, „Lamus” Lwów 1913.

2 J. G. Pawlikowski, Prawo ochrony przyrody, Kraków 1927.

3 J. J. Nowak, Problemy administracyjne ochrony przyrody, Kraków 1939.

4 W. Brzeziński, Ochrona prawna biologicznego środowiska człowieka, Warszawa 1971, powtórzone po czterech latach pod zmienionym tytułem Ochrona prawna naturalnego środowiska człowieka, Warszawa 1975.

${ }^{5}$ L. Łustacz (red.), Prawo a ochrona środowiska, „Ossolineum” 1975. 
wczesnych publikacji ochronie środowiska poświęconych ${ }^{6}$. Wreszcie trzeci z nich, Ludwik Jastrzębski, znawca prawnych zagadnień przede wszystkim leśnictwa, łowiectwa i ochrony przyrody, zapisał się w literaturze dwoma wydaniami skryptu ${ }^{7}$, przekształconego następnie $\mathrm{w}$ podręcznik ${ }^{8}$ prawa ochrony środowiska oraz odrębną monografią poświęconą prawnej ochronie przyrody ${ }^{9}$.

Trzej wymienieni zajmowali się ochroną środowiska zasadniczo od strony prawa administracyjnego, ale idee ochrony środowiska zaczęły stopniowo wnikać do prawa cywilnego, karnego i międzynarodowego. Przypomnieć w tym miejscu trzeba postacie cywilistów Stefana Grzybowskiego, który w swoich artykułach ${ }^{10}$ kładł podwaliny pod cywilistyczne myślenie o ochronie środowiska, i Antoniego Agopszowicza, wybitnego znawcy prawa górniczego ${ }^{11}$, ale także współautora i redaktora pierwszego katowickiego opracowania dotyczącego ochrony środowiska ${ }^{12}$, którego pomysły interpretacyjne cywilistycznych rozwiązań ustawy o ochronie środowiska ${ }^{13}$ wytrzymały próbę czasu i do dziś są w cywilistyce powoływane. Przywołać trzeba karnistkę Genowefę Rejman, której skrypt ${ }^{14}$ był pierwszą w literaturze polskiej pozycją poświęconą prawu karnemu środowi-

6 L. Łustacz (red.), Ochrona środowiska. Refleksje prawne, ekonomiczne i socjologiczne, „Ossolineum” 1979.

7 L. Jastrzębski, Ochrona prawna przyrody i środowiska $w$ Polsce. Zagadnienia administracyjne, Warszawa 1976 oraz Ochrona prawna przyrody i środowiska w PRL. Zagadnienia administracyjne, Warszawa 1979.

8 L. Jastrzębski, Ochrona środowiska $w$ PRL. Zagadnienia administracyjne, Warszawa 1983 oraz Prawo ochrony środowiska w Polsce, Warszawa 1990.

9 L. Jastrzębski, Prawne zagadnienia ochrony przyrody, Warszawa 1980.

10 S. Grzybowski, Problematyka ochrony środowiska a przepisy prawa cywilnego, „Państwo i Prawo” 1972, z. 1 oraz Problemy ochrony środowiska człowieka a zadania prawa cywilnego, „Krakowskie Studia Prawnicze” 1977, rocznik X.

11 A. Agopszowicz, Zarys systemu prawnego górnictwa, Katowice 1991.

12 A. Agopszowicz (red.), Wybrane zagadnienia biologiczno-prawne ochrony i kształtowania środowiska, Katowice 1975.

13 A. Agopszowicz, Cywilnoprawne środki ochrony środowiska $w$ świetle ustawy o ochronie i kształtowaniu środowiska, [w:] K. Podgórski (red.), Zagadnienia prawne ochrony środowiska, Katowice 1981.

14 G. Rejman, Ochrona środowiska w prawie karnym, Warszawa 1977. 
ska. Spośród internacjonalistów wspomnieć należy Kazimierza Kocota, którego monografia ${ }^{15}$ dała początek polskim badaniom ochrony środowiska w prawie międzynarodowym.

Szczególne we wspomnieniach miejsce należy się Jerzemu Sommerowi, wieloletniemu kierownikowi Zakładu Prawa Ochrony Środowiska Instytutu Nauk Prawnych PAN, założycielowi i prezesowi Towarzystwa Naukowego Prawa Ochrony Środowiska, twórcy wydawnictwa tegoż Towarzystwa, pomysłodawcy i redaktora kwartalnika „Ochrona Środowiska. Prawo i Polityka". W większości spośród blisko 60 pozycji Wydawnictwa Towarzystwa Jerzy Sommer był autorem, współautorem i redaktorem naukowym, a co najmniej recenzentem bądź konsultantem dbającym o odpowiedni poziom opracowania. Wystarczy wskazać na komentarze do ustawy z 1980 r. o ochronie i kształtowaniu środowiska ${ }^{16}$ i ustawy z 1991 r. o ochronie przyrody $^{17}$, a jego podstawowe dzieło teoretyczne ${ }^{18}$ jest do dziś powoływane we wszystkich podręcznikach prawa ochrony środowiska.

Karol Podgórski zapisał się nauce prawa ochrony środowiska nie tylko jako znawca prawa wodnego ${ }^{19}$, ale także jako autor pierwszego w tej dziedzinie studium prawnoporównawczego $^{20}$. Postać Michała Kuleszy kojarzy nam się przede wszystkim z prawem samorządowym, ale nie można zapomnieć, że był on wybitnym znawcą zagadnień tak bliskich ochronie środowiska, jak planowanie przestrzenne ${ }^{21}$, a także autorytetem $\mathrm{w}$ dziedzi-

15 K. Kocot, Prawnomiędzynarodowe zasady sozologii, Warszawa-Wrocław 1977.

16 J. Sommer (red.), Ustawa o ochronie i kształtowaniu środowiska. Komentarz, wydanie pierwsze Wrocław 1995, wydanie drugie Wrocław 1999.

17 J. Sommer (red.), Ustawa o ochronie przyrody. Komentarz, cztery wydania z lat 1992, 1994, 1997 i 2001 oraz suplement z 2002 r.

18 J. Sommer, Efektywność prawa ochrony środowiska i jej uwarunkowania - problemy udatności jego struktury, Wrocław 2005.

19 K. Podgórski, Ochrona wód przed zanieczyszczeniem $w$ świetle prawa administracyjnego, Warszawa 1974.

20 K. Podgórski, Ochrona środowiska $w$ PRL i sąsiednich krajach socjalistycznych, Katowice 1977.

21 M. Kulesza, Administracyjnoprawne uwarunkowania polityki przestrzennej, Warszawa 1987. 
nie prawnej ochrony przyrody, autorem subtelnej analizy relacji między ochroną środowiska a ochroną przyrody ${ }^{22}$. Wspomnę także Waleriana Pańkę, z którego badań dotyczących prawa gruntowego do dziś korzystają autorzy zajmujący się zagadnieniami prawnymi ochrony i gospodarowania zasobami naturalnymi, a napisany przez niego wraz z Michałem Kuleszą referat o ochronie środowiska $\mathrm{w}$ planowaniu ${ }^{23}$ może i dziś być wzorcem myślenia o planowaniu gospodarczym i przestrzennym w ochronie środowiska. Przypomnę Jana Szachułowicza i cztery wydania jego komentarza do prawa wodnego ${ }^{24}$. Nie zapomniałem o jakże przedwcześnie zmarłej Małgorzacie Longchamps, która zdążyła się zapisać w nauce prawa ochrony środowiska wielce oryginalną koncepcją odpowiedzialności za szkodę w środowisku ${ }^{25}$.

Ruszamy w drogę.

\section{PASEM PÓŁNOCNYM}

Zaczynamy od Szczecina, o którym do niedawna niewiele dobrego można było $\mathrm{w}$ aspekcie prawnej ochrony środowiska powiedzieć. Ale wystarczyło, aby na Uniwersytet Szczeciński przyszedł Marek Górski (poznamy go bliżej, gdy będziemy w Łodzi), aby pokłosiem konferencji poświęconej Naturze 2000 stał się obszerny tom ${ }^{26}$, którego podstawowy walor polega na umiejętnym połączeniu analiz teoretycznych z doświadczeniami praktycznymi, a także aby ukazała się znakomita monografia

22 M. Kulesza, Ochrona środowiska i ochrona przyrody. Spór o ujęcie legislacyjne, „Gazeta Prawnicza” 1988, nr 18.

${ }_{23}$ M. Kulesza, W. Pańko, Ochrona środowiska a cele i zadania planowania, [w:] J. Sommer (red.), Ochrona środowiska w planowaniu, Wrocław 1984.

24 J. Szachułowicz, Nowe prawo wodne z komentarzem, Warszawa 2002, kolejne wydania w latach 2006, 2007 i 2010.

25 M. Longchamps, Odpowiedzialność za szkodę ekologiczna, Wrocław 1986.

${ }^{26}$ Problemy wdrażania systemu Natura 2000 w Polsce, pod red. A. Kaźmierskiej-Patrzycznej i M. A. Król, Szczecin-Łódź-Poznań 2013. 
Anny Barczak poświęcona gospodarowaniu odpadami komunalnymi w Polsce i Niemczech ${ }^{27}$.

Żegnamy Szczecin i udajemy się do Gdańska, gdzie na Uniwersytecie Gdańskim oczekuje nas Zdzisław Brodecki, znawca problematyki ochrony środowiska morskiego ${ }^{28}$, współautor znaczących pozycji w dziedzinie unijnego prawa ochrony środowiska ${ }^{29}$. Ale Gdańsk to także Janina Ciechanowicz-McLean, autorka jednego z pierwszych całościowych podręczników prawa ochrony środowiska ${ }^{30}$, która po początkowym zainteresowaniu przede wszystkim prawem międzynarodowym ${ }^{31}$ przeszła do ochrony środowiska w działalności gospodarczej ${ }^{32}$, współautorka komentarza do ustawy - Prawo ochrony środowiska ${ }^{33}$, współautorka i redaktorka znaczącego dzieła teoretycznego o prawie ochrony przyrody ${ }^{34}$. Obok tej dwójki wymienię Leszka Meringa, zajmującego się przede wszystkim prawnokarną ochroną środowiska $^{35}$, ale także autora jednego z pierwszych opracowań zestawiających unijne i polskie prawo ochrony środowiska ${ }^{36}$.

27 A. Barczak, Model gospodarowania odpadami komunalnymi w Polsce i Niemczech. Analiza prawnoporównawcza, Szczecin 2013.

28 Z. Brodecki, Odpowiedzialność za zanieczyszczenie morza, Gdańsk 1983.

29 Z. Brodecki, E. Gończ, D. Lost-Siemińska, S. Majkowska, F. Pankau, D. Pyć, A. Tyszecki, Ochrona środowiska. Acquis communautaire, Warszawa 2005 oraz Z. Brodecki, T. Koncewicz, P. Kupczyk, M. Pchałek, Ochrona przyrody przed Europejskim Trybunałem Sprawiedliwości. Komentarz, Marki 2010.

30 J. Ciechanowicz, Prawo ochrony środowiska, Koszalin 1995.

31 J. Ciechanowicz, Międzynarodowe prawo ochrony środowiska, wydanie I - Warszawa 1999, wydanie II - Warszawa 2002.

32 J. Ciechanowicz-McLean, Ochrona środowiska $w$ działalności gospodarczej, Warszawa 2003.

33 J. Ciechanowicz-McLean, Z. Bukowski, B. Rakoczy, Prawo ochrony środowiska. Komentarz, Warszawa 2008.

34 J. Ciechanowicz-McLean (red.), K. Biernat, P. Mierzejewski, D. Trzcińska, Polskie prawo ochrony przyrody, Warszawa 2006.

35 L. Mering, Ochrona środowiska $w$ nowym kodeksie karnym, „Gdańskie Studia Prawnicze” 1999, tom IV; Środowisko jako przedmiot ochrony karnoprawnej, „Gdańskie Studia Prawnicze” 2005, t. XIV; Prawo karne w ochronie środowiska - przedmiot ochrony, "Ochrona Środowiska. Prawo i polityka” 2007, nr 3.

${ }^{36}$ L. Mering, Ochrona środowiska $w$ prawie wspólnotowym $i$ w prawie polskim. Harmonizacja polskiego prawa ochrony środowiska z normami prawa Wspólnot Europejskich, Sopot 1999. 
Zostawiamy Gdańsk i udajemy się do Białegostoku, aby zachwycić się niezwykłą urodą Ewy Katarzyny Czech, ale po drodze wpadniemy jeszcze na Uniwersytet Warmińsko-Mazurski w Olsztynie, aby pogratulować Urszuli Szymańskiej i Elżbiecie Zębek niezwykle udanego skryptu prawa ochrony środowiska ${ }^{37}$. Korzystając z okazji, że jesteśmy w Olsztynie, odwiedzimy jeszcze Wiesława Pływaczewskiego, aby docenić dwa cenne zbiory pokonferencyjne poświęcone prawnokarnym aspektom ochrony środowiska ${ }^{38}$.

Przybywamy na Uniwersytet Białostocki, odnotowując wybitną monografię Ewy Katarzyny Czech poświęconą odpowiedzialności administracyjnej za szkody w środowisku ${ }^{39}$ i nie zapominając o jej poprzednich dokonaniach ${ }^{40}$. Skorzystamy z okazji, że jesteśmy w Białymstoku, i odwiedzimy jeszcze Mieczysława Goettla, doceniając jego cenną monografię cywilistyczną ${ }^{41}$.

Wracamy na zachód i rozpoczynamy drugi etap naszej wędrówki.

\section{PASEM ŚRODKOWYM}

Na Uniwersytecie Adama Mickiewicza w Poznaniu odnotowujemy monografię Jerzego Małeckiego poświęconą prawnofinansowym instrumentom ochrony środowiska ${ }^{42}$, o tyle znaczącą, że pierwszą w naszej literaturze analizującą te zagadnienia.

37 U. Szymańska, E. Zębek, Prawo i ochrona środowiska - prawne, ekonomiczne, ekologiczne i techniczne aspekty ochrony środowiska naturalnego, Olsztyn 2008; opracowanie kilkakrotnie wznawiane.

38 W. Pływaczewski (red.), Prawnokarne i kryminologiczne aspekty ochrony środowiska, Olsztyn 2012; W. Pływaczewski, M. Duda (red.), Nielegalna eksploatacja obszarów leśnych, Olsztyn 2013.

39 E. K. Czech, Szkoda $w$ obszarze środowiska $i$ wina jako determinanty odpowiedzialności administracyjnej za tę szkodę, Białystok 2008.

40 E. K. Czech (red.), Uwarunkowania ochrony środowiska. Aspekty krajowe, unijne, międzynarodowe, Warszawa 2006.

${ }^{41}$ M. Goettel, Sytuacja zwierzęcia w prawie cywilnym, Warszawa 2013.

42 J. Małecki, Prawnofinansowe instrumenty ochrony $i$ kształtowania środowiska, Poznań 1982. 
Przy okazji pobytu w Poznaniu zauważamy Spółkę z o.o. Abrys wydającą pięć periodyków zajmujących się ochroną środowiska: „Przegląd Komunalny”, „Recykling”, „Czysta Energia”, „Wodociągi i Kanalizacja”, „Zieleń Miejska”. Wprawdzie nie są to czasopisma prawnicze, ale poświęcają nieco miejsca także zagadnieniom prawnym. Do nich trzeba pisać krótko, zwięźle i w sposób zrozumiały dla nieprawników. Na ich łamach publikują prawnicy - mistrzowie małych form: Marek Górski, Jan Jerzmański, Bartosz Draniewicz, Krzysztof Gruszecki, Zbigniew Bukowski, Piotr Korzeniowski, Magdalena Bar, Aneta Kaźmierska-Patrzyczna. Nie bez powodu zwracam uwagę na te czasopisma, nie jest bowiem wielką sztuką napisanie kilkudziesięciostronicowego artykułu, ale trzeba się wykazać nie lada kunsztem, aby na 5, 3 lub nawet 1 stronie napisać coś sensownego o prawnej ochronie środowiska, a to potrafią wskazani autorzy.

Udajemy się dalej na wschód, zatrzymując się najpierw w Bydgoszczy na Uniwersytecie Kazimierza Wielkiego. Bydgoszcz to przede wszystkim Ryszard Paczuski, autor najważniejszego podręcznika prawa ochrony środowiska z lat poprzedzających wielką reformę 2001 roku $^{43}$, który po jej wejściu w życie dostosował do niej swe największe osiągnięcia teoretyczne ${ }^{44}$, wybitny znawca problematyki spółek wodnych ${ }^{45}$, autor bodaj jedynego w naszym piśmiennictwie opracowania poświęconego problematyce prawnej uzdrowisk ${ }^{46}$. Z tym uniwersytetem związany jest także Zbigniew Bukowski, autor o szerokim wachlarzu osiągnięć naukowych, od problematyki administracyjnej ${ }^{47}$, poprzez

43 R. Paczuski, Prawo ochrony środowiska, wydanie I - Bydgoszcz 1994, wydanie II - Bydgoszcz 1996, wydanie III - Bydgoszcz 2000.

44 R. Paczuski, Ochrona środowiska. Zarys wykładu, Bydgoszcz 2008.

45 R. Paczuski, Spótki wodne. Historia, prawne podstawy działania, nowe tendencje, Warszawa 1989; Spótki wodne - cele, zadania, prawne podstawy organizacji oraz perspektywy ich rozwoju w kontekście zachodzących zmian, Toruń 2006.

46 R. Paczuski, Ochrona zasobów leczniczych środowiska przyrodniczego Rzeczypospolitej Polskiej. Zagadnienia administracyjnoprawne, Warszawa 1990.

47 Z. Bukowski, Podstawy prawa ochrony środowiska dla administracji, Włocławek 2005; Postępowanie administracyjne $w$ sprawach z zakresu ochrony środowiska, Bydgoszcz-Włocławek 2006; Postępowanie administracyjne 
prawo międzynarodowe ${ }^{48}$ i unijne ${ }^{49}$, do swego największego dzieła poświęconego zasadzie zrównoważonego rozwoju ${ }^{50}$. Bydgoszcz to także Krzysztof Gruszecki, którego kilkakrotnie wznawiane komentarze do najważniejszych ustaw: Prawa ochrony środowiska ${ }^{51}$, ustawy o ochronie przyrody ${ }^{52}$ i ustawy o ocenach oddziaływania na środowisko ${ }^{53}$, budzą szacunek.

Zostawiamy Bydgoszcz i udajemy się na Uniwersytet Mikołaja Kopernika w Toruniu, gdzie oczekuje nas czarująca Karolina Karpus, komentatorka najważniejszych części ustawy o odpadach $^{54}$, autorka lub współautorka innych wartościowych pozycji. Torun to jednak przede wszystkim Bartosz Rakoczy, autor licznych monografii ${ }^{55}$, autor i współautor komentarzy do najważniejszych ustaw ochronnych ${ }^{56}$, współautor wraz z Błażejem

w sprawach z zakresu ocen oddziaływania na środowisko, Toruń-Włocławek 2010.

48 Z. Bukowski, Prawo międzynarodowe a ochrona środowiska, Toruń 2005.

49 Z. Bukowski, Prawo ochrony środowiska Unii Europejskiej, Warszawa 2007.

50 Z. Bukowski, Zrównoważony rozwój w systemie prawa, Toruń 2009.

51 K. Gruszecki, Prawo ochrony środowiska. Komentarz, Warszawa 2007, wydanie 2 - Warszawa 2008, wydanie 3 - Warszawa 2011.

52 K. Gruszecki, Ustawa o ochronie przyrody. Komentarz, Kraków 2005, wydanie 2 - Warszawa 2010, wydanie 3 - Warszawa 2013.

53 K. Gruszecki, Ustawa o udostępnianiu informacji o środowisku i jego ochronie, udziale społeczeństwa $w$ ochronie środowiska oraz o ocenach oddziaływania na środowisko. Komentarz, Wrocław 2009, wydanie 2 - Wrocław 2010.

54 B. Rakoczy, K. Karpus, Ustawa o odpadach. Komentarz, pod red. B. Rakoczego, Warszawa 2013.

55 B. Rakoczy, Ograniczenie praw i wolności jednostki ze względu na ochronę środowiska w Konstytucji Rzeczypospolitej Polskiej, Toruń 2006; Ciężar dowodu w polskim prawie ochrony środowiska, Warszawa 2010; Utrzymanie czystości i porządku w gminie w prawie polskim, Warszawa 2013; Usuwanie drzew i krzewów, Warszawa 2013.

56 B. Rakoczy, Komentarz do ustawy o zapobieganiu szkodom w środowisku i ich naprawie, Warszawa 2008; Ustawa o udostępnianiu informacji o środowisku i jego ochronie, udziale społeczeństwa $w$ ochronie środowiska oraz o ocenach oddziaływania na środowisko. Komentarz, Warszawa 2010; Ustawa o lasach. Komentarz, Warszawa 2011, a także B. Rakoczy (red.), Z. Bukowski, K. Szuma, Prawo wodne. Komentarz, Warszawa 2013; Z. Bukowski, E. K. Czech, K. Karpus, B. Rakoczy, Prawo ochrony środowiska. Komentarz, Warszawa 2013; B. Rakoczy, R. Stec, A. Woźniak, Prawo łowieckie. Komentarz, Warszawa 2014. 
Wierzbowskim podręcznika prawa ochrony środowiska ${ }^{57}$. Wielką zasługą Bartosza Rakoczego i Karoliny Szumy jest uprzystępnienie czytelnikowi polskiemu włoskiego prawa środowiska ${ }^{58}$. Toruń na polskiej mapie nauki o prawie ochrony środowiska zapisuje się także dwoma znakomitymi periodykami: „Przegląd Prawa Ochrony Środowiska” oraz „Polish Yearbook of Environmental Law".

Z żalem zostawiamy przepiękny Toruń i wędrujemy do Warszawy, gdzie odnotowujemy najpierw Edwarda Radziszewskiego, znawcę prawa budowlanego i jego styku z prawem ochrony środowiska ${ }^{59}$, pierwszego komentatora ustawy z 1980 r. o ochronie środowiska ${ }^{60}$, autora komentarza także do ustawy obowiązującej ${ }^{61}$. Pozycję Uniwersytetu Warszawskiego ugruntowuje Maria Magdalena Kenig-Witkowska, autorka opracowań poświęconych systemom międzynarodowego i unijnego prawa środowiska ${ }^{62}$ oraz zbioru przepisów międzynarodowych i unijnych ${ }^{63}$. Jeśli chodzi o zbiory przepisów, to wprawdzie wszystko jest w Internecie, ale Internet Internetem, a książka książką, którą można wziąć do ręki, powąchać, pogłaskać, przytulić, a tego z ekranem komputera zrobić się nie da. Dlatego preferujący „cywilizację książkową” przed „cywilizacją komputerową" wdzięczni są autorce za te zbiory i zwięzłe a trafne wprowadzenia do nich. Warszawa to także Leszek Karski

57 B. Wierzbowski, B. Rakoczy, Prawo ochrony środowiska. Zagadnienia podstawowe, Warszawa, pięć wydań w latach 2004-2012.

58 B. Rakoczy, K. Szuma, Norme in materia ambientale - Codice dell'ambiente. Wtoski kodeks środowiskowy, Warszawa 2013.

59 E. Radziszewski, Ochrona środowiska a budownictwo. Poradnik techniczno-prawny, Warszawa 1985.

60 E. Radziszewski, Ustawa o ochronie i kształtowaniu środowiska. Komentarz. Przepisy wykonawcze, Warszawa 1987.

61 E. Radziszewski, Prawo ochrony środowiska. Przepisy i komentarz, Warszawa 2003.

62 M. M. Kenig-Witkowska, Międzynarodowe prawo środowiska. Wybrane zagadnienia systemowe, Warszawa 2009; Prawo środowiska Unii Europejskiej. Zagadnienia systemowe, Warszawa 2005.

63 Międzynarodowe prawo środowiska. Wybór i wprowadzenie M. M. Kenig-Witkowska, Warszawa 2009; Prawo środowiska Unii Europejskiej. Wybór i wprowadzenie M. M. Kenig-Witkowska, Warszawa 2012. 
z Uniwersytetu Stefana Kardynała Wyszyńskiego, zajmujący się problematyką prawną klimatu ${ }^{64}$. Z Warszawą związany jest Bartosz Draniewicz, autor przydatnych komentarzy ${ }^{65}$, znawca problematyki ekonomicznej i finansowej ochrony środowiska, z zagadnieniami opłaty produktowej na czele ${ }^{66}$. W Warszawie mamy także Jana Józefa Skoczylasa, autora jedynej jak na razie całościowej monografii cywilistycznej ${ }^{67}$, szkoda, że napisanej na mocno starym stanie prawnym, a trudno zakładać, że powtórzy ją na nowym, skoro porzucił prawo ochrony środowiska na rzecz innych segmentów nauki prawa i tylko od czasu do czasu daje znać, że o prawnej ochronie środowiska nie zapomniał ${ }^{68}$.

Opuszczamy Warszawę i zmierzamy w stronę Lublina, ale po drodze wpadniemy najpierw do Piaseczna, aby uścisnąć dłoń Jackowi Zyśkowi, wydawcy kilku periodyków poświęconych ochronie środowiska z kwartalnikiem „Prawo i Środowisko” na czele, w którym publikują nie tylko uznani autorzy, ale i młodzi adepci naszej dziedziny nauki prawa, następnie na Uniwersytet Przyrodniczo-Humanistyczny w Siedlcach, aby docenić zasługi Romana Steca dla rozwoju nauki o prawie łowieckim ${ }^{69}$.

Przybywamy do Lublina, gdzie na Uniwersytecie Marii Curie-Skłodowskiej oczekują nas Anna Przyborowska-Klimczak, autorka znakomitego studium o międzynarodowej ochronie przyrody $^{70}$, oraz Jerzy Stelmasiak, redaktor i współautor pod-

${ }^{64}$ L. Karski, I. Grochowska (red.), Zmiany klimatu a społeczeństwo, Warszawa 2010.

65 B. Draniewicz, Gospodarowanie odpadami i opakowaniami - opłaty. Komentarz, Warszawa 2005; Recykling pojazdów wycofanych z eksploatacji. Komentarz, Warszawa 2006.

66 B. Draniewicz, Opłata produktowa, Warszawa 2009.

67 J. J. Skoczylas, Cywilnoprawne środki ochrony środowiska, Warszawa 1986.

68 J. J. Skoczylas, Odpowiedzialność cywilna na podstawie ustawy - Prawo ochrony środowiska, „Przegląd Sądowy” 2003, nr 4.

69 R. Stec, Łowiectwo w prawie polskim i europejskim, Warszawa 2002; Prawo łowieckie. Wybrane aspekty prawnoporównawcze, Warszawa 2009; Uprawianie łowiectwa i prowadzenie gospodarki łowieckiej. Uwarunkowania administracyjnoprawne, cywilnoprawne i organizacyjne, Warszawa 2012.

70 A. Przyborowska-Klimczak, Ochrona przyrody. Studium prawnomiędzynarodowe, Lublin 2004. 
ręcznika lubelskiego ${ }^{71}$, wybitny znawca problematyki planowania przestrzennego ${ }^{72}$ oraz obszarów specjalnych ${ }^{73}$. Jest on także sędzią Naczelnego Sądu Administracyjnego; warto uzmysłowić sobie, że za co ciekawszymi pomysłami interpretacyjnymi wyrażonymi w orzecznictwie stoi (a raczej siedzi, jako że orzeka się i uzasadnienia orzeczeń pisze się zwykle na siedząco) właśnie Jerzy Stelmasiak. Będąc w Lublinie, nie zapominamy o Annie Haładyj, Kamili Sobieraj i Macieju Rudnickim z Katolickiego Uniwersytetu Lubelskiego, którzy współtworzyli i jakże umiejętnie zredagowali dwutomowe dzieło poświęcone europeizacji prawa ochrony środowiska ${ }^{74}$. Lublin to także Janusz Stochlak, rzetelnie dokumentujący i omawiający przemiany polskiego prawa ochrony środowiska ${ }^{75}$.

Z Lublina wrócimy na lewą stronę mapy przez Łódź. Uniwersytet Łódzki to przede wszystkim Marek Górski, autor o niezwykle szerokim zakresie zainteresowań naukowych obejmującym zagadnienia organizacyjne ${ }^{76}$, odpowiedzialność administracyjnoprawną ${ }^{77}$, problematykę postępowania z odpadami ${ }^{78}$,

71 J. Stelmasiak (red.), Prawo ochrony środowiska, wydanie 1 - Warszawa 2009, wydanie 2 - Warszawa 2010.

72 J. Stelmasiak, Miejscowy plan zagospodarowania przestrzennego jako prawny środek ochrony środowiska, Lublin 1994.

73 J. Stelmasiak, Instytucja strefy ochronnej jako prawny środek ochrony środowiska, Lublin 1986; Interes indywidualny a interes publiczny $w$ ochronie środowiska w obszarze specjalnym o charakterze ekologicznym, Rzeszów 2013.

74 M. Rudnicki, A. Haładyj, K. Sobieraj (red.), Dekada harmonizacji w prawie ochrony środowiska, Lublin 2011; Europeizacja prawa ochrony środowiska, Lublin 2011.

75 J. Stochlak, Polskie prawo ochrony środowiska. Uwarunkowania, zmiany, stan, Warszawa 2002 oraz liczne artykuły na łamach „Prawa i Środowiska”.

76 M. Górski, Ochrona środowiska jako zadanie administracji publicznej, Łódź 1992.

77 M. Górski, Odpowiedzialność administracyjnoprawna w ochronie środowiska, Warszawa 2008.

78 M. Górski, Gospodarowanie odpadami w świetle wymagań prawa wspólnotowego i polskiego prawa wewnętrznego, Poznań 2005, a także M. Górski, K. Nowacki (red.), Prawne i organizacyjne obowiązki gmin $w$ postępowaniu z odpadami komunalnymi, Wrocław 2012; Zadania i obowiazki gmin $w$ postępowaniu z odpadami komunalnymi, Wrocław 2013 oraz M. Górski, K. Rynkiewicz, Ustawa o opakowaniach i odpadach opakowaniowych. Komentarz, Warszawa 2009. 
a nawet ochronę środowiska morskiego ${ }^{79}$. Ale Łódź to nie tylko Marek Górski, lecz również aniołki Górskiego: Anna Barczak, Joanna Sylwia Kierzkowska, Joanna Miłkowska-Rębowska, Aneta Kaźmierska-Patrzyczna, Monika Król i inne, które wraz z Markiem Górskim i jeszcze innymi autorami napisały podręcznik łódzki ${ }^{80}$, a także niezwykle interesującą monografię poświęconą różnorodności biologicznej ${ }^{81}$. Uniwersytet Łódzki to nie tylko Marek Górski i jego aniołki, ale także Piotr Korzeniowski, nie tylko mistrz małych form, lecz i arcymistrz form wielkich, autor fundamentalnych dzieł dotyczących zasad ochrony środowiska ${ }^{82}$ oraz bezpieczeństwa ekologicznego ${ }^{83}$. Przebrnięcie przez dwie ostatnie pozycje liczące łącznie ponad tysiąc stron wymaga niejakiego samozaparcia, ale zapewniam - warto. Jeżeli jesteśmy już na Uniwersytecie Łódzkim, przywołajmy Ryszarda Dębskiego i Wojciecha Jana Katnera, którzy wnieśli znaczący wkład $\mathrm{w}$ teorię prawa ochrony środowiska: pierwszy $\mathrm{w}$ aspekcie karnistycznym ${ }^{84}$, drugi cywilistycznym ${ }^{85}$, ale potem porzucili prawo ochrony środowiska dla innych dziedzin nauki prawa.

Z Łodzi udajemy się do Wrocławia, aby rozpocząć ostatni etap naszej wędrówki.

79 M. Górski, Ochrona prawna środowiska naturalnego Morza Battyckiego, Łódź 1987.

80 M. Górski (red.), Prawo ochrony środowiska, Warszawa 2009, wydanie 2 - Warszawa 2014.

81 M. Górski, J. Miłkowska-Rębowska (red.), Prawo ochrony różnorodności biologicznej, Warszawa 2013.

82 P. Korzeniowski, Zasady prawne ochrony środowiska, Łódź 2010.

83 P. Korzeniowski, Bezpieczeństwo ekologiczne jako instytucja prawna ochrony środowiska, Łódź 2012.

84 R. Dębski, Przestępstwa przeciwko środowisku w kodeksie karnym - rozważania de lege ferenda, „Studia Kryminologiczne, Kryminalistyczne i Penitencjarne", t. 21, Warszawa 1990.

85 W. J. Katner, Ochrona własności nieruchomości przed naruszeniami pośrednimi, Warszawa 1982. 


\section{PASEM POŁUDNIOWYM}

Wrocław jest miastem wielce znaczącym na mapie nauki prawa ochrony środowiska, w nim bowiem mają siedzibę trzy instytucje naukowe zajmujące się tą dziedziną; w kolejności chronologicznej: Uniwersytet Wrocławski, Zakład Prawa Ochrony Środowiska INP PAN, Centrum Prawa Ekologicznego.

Zaczniemy od Uniwersytetu Wrocławskiego. Senior polskiej nauki o prawie środowiska, internacjonalista Karol Wolfke, swym podstawowym dziełem ${ }^{86}$ trwale wpisał się w doktrynę międzynarodowego prawa środowiska, gdyż mimo upływu lat jest ono powoływane we wszystkich liczących się opracowaniach z tej dziedziny. Sędzia Trybunału Konstytucyjnego w stanie spoczynku, Marek Mazurkiewicz, zapisał się nie tylko swymi opracowaniami dotyczącymi instrumentów finansowych ${ }^{87}$, ale także wnikliwymi analizami konstytucyjnoprawnej ochrony środowiska $^{88}$. Nauka prawnej ochrony środowiska na Uniwersytecie Wrocławskim to jednak przede wszystkim Jan Boć, autor jednego z pierwszych skryptów jej poświęconych ${ }^{89}$, współautor pionierskiego wówczas opracowania o dostępie do informacji ${ }^{90}$, współautor wraz z Konradem Nowackim i Elżbietą Samborską-Boć podręcznika, który doczekał się ośmiu wydań ${ }^{91}$. Konrad Nowacki wpisał się $\mathrm{w}$ naukę prawa ochrony środowiska zna-

86 K. Wolfke, Międzynarodowe prawo środowiska. Tworzenie i egzekwowanie, Wrocław 1979.

87 M. Mazurkiewicz, Opłaty i kary pieniężne w systemie ochrony środowiska w Polsce (struktura prawna i funkcje), Wrocław 1986.

88 M. Mazurkiewicz, Regulacja konstytucyjna ochrony środowiska w Polsce, [w:] H. Lisicka (red.), Ochrona środowiska w polityce, Wrocław 1999.

89 J. Boć, Zagadnienia prawne ochrony środowiska naturalnego, Wrocław 1979.

90 J. Boć, J. Jendrośka, K. Nowacki, G. Winter, Dostęp do informacji i akt w sferze ochrony środowiska, Wrocław 1990.

91 J. Boć, K. Nowacki, E. Samborska-Boć, Ochrona środowiska, Wrocław 2000, kolejne wydania w latach 2001, 2002, 2003, 2004, 2005, 2006 i 2008. 
czącym studium komparatystycznym ${ }^{92}$. Ich dzieło kontynuują młodsi ${ }^{93}$.

Przejdę do Zespołu (następnie Zakładu) Zagadnień Prawnych Kształtowania i Ochrony Środowiska Instytutu Państwa i Prawa (następnie Nauk Prawnych) PAN powołanego do życia 1 grudnia 1976 r. z inicjatywy ówczesnego dyrektora Instytutu Adama Łopatki przy wsparciu ówczesnego dziekana Wydziału Prawa i Administracji Uniwersytetu Wrocławskiego Aleksandra Patrzałka, który na potrzeby naszego Zespołu przeznaczył pomieszczenie w budynku należącym do Wydziału. Zaczynaliśmy skromnie: Jerzy Sommer, kierownik Zespołu, Bernadetta Latajka-Ostenda i ja. Stopniowo dochodzili zajmujący do dziś znaczące miejsce $\mathrm{w}$ nauce prawa ochrony środowiska: Jerzy Jendrośka, Jerzy Rotko, Jan Jerzmański, Adam Habuda, a także inni, niektórzy odeszli. Najdłużej pracowaliśmy w szóstkę, ale ostatecznie pozostaliśmy we trzech: Jerzy Rotko, wybitny znawca prawa wodnego: unijnego ${ }^{94}$, polskiego ${ }^{95}$ i niemieckiego ${ }^{96}$, Adam Habuda, autor jedynej jak dotychczas kompleksowej analizy prawnej systemu Natura $2000^{97} \mathrm{i}$ ja. Poza serią komentarzy do ustaw ochronnych do najważniejszych zespołowych osiągnięć Zakładu należą: przedstawienie konstrukcji prawa podmiotowego do środowiska ${ }^{98}$, zbadanie relacji między prawem własności a ochroną środowiska99 ${ }^{99}$ przestawienie podstaw teo-

92 K. Nowacki, Administracyjnoprawne instrumenty ochrony środowiska naturalnego $w$ Republice Federalnej Niemiec i Austrii. Studium prawnoporównawcze, Wrocław 1993.

93 J. Boć, A. Chajbowicz, I. Białowąs, A. Haręża, Ł. Mikowski, Prawo ochrony środowiska. Konwersatoria, Wrocław 2009.

94 J. Rotko, Ramowa dyrektywa wodna - analiza prawna, Poznań 2013.

95 J. Rotko (red.) Prawo wodne. Komentarz, Wrocław 2002; a także J. Rotko, Podstawy prawne gospodarki wodnej, Wrocław 2006.

96 J. Rotko, Instrumenty administracyjnoprawne ochrony środowiska w RFN - ze szczególnym uwzględnieniem ochrony wód, Wrocław 1998.

97 A. Habuda, Obszary Natura 2000 w prawie polskim, Warszawa 2013.

98 Prawo człowieka do środowiska naturalnego, pod red. J. Sommera, Wrocław 1987.

4/2014 2000.

99 Ochrona środowiska a prawo własności, pod red. J. Sommera, Wrocław 
retycznych prawnej ochrony przyrody ${ }^{100}$ oraz koncepcji zintegrowanej ochrony środowiska ${ }^{101}$. W 2010 r. Zakład zdobył się na obszerne dzieło teoretyczne ${ }^{102}$, dołączając w ten sposób do tych ośrodków naukowych, które mogą pochwalić się opracowaniem o charakterze podręcznikowym. Współpracująca z nami Halina Lisicka kontynuuje wydawanie kwartalnika „Ochrona Środowiska. Prawo i polityka”.

Ważnym kierunkiem działalności naukowej wrocławskiego Zakładu jest współpraca z czeskimi i słowackimi prawnikami zajmującymi się ochroną środowiska, nawiązana w 2000 r. i kontynuowana do dziś. Znalazła ona wyraz w 15 konferencjach naukowych organizowanych na przemian przez trzy państwa. W pierwszych sześciu konferencjach ze strony polskiej brali udział tylko prawnicy i politolodzy wrocławscy, ale począwszy od siódmej w Dusznikach Zdroju w 2006 r. dołączali przedstawiciele ośrodków katowickiego, gdańskiego i lubelskiego, a w kolejnych także łódzkiego, bydgoskiego i toruńskiego, dziś więc te konferencje można określić mianem przedsięwzięć naukowych ogólnopolskich. Materiały konferencji organizowanych przez stronę polską były wydawane z tłumaczeniami referatów czeskich i słowackich na język polski ${ }^{103}$, co wzbogaciło polską literaturę poświęconą prawnej ochronie środowiska o rozważania autorów czeskich i słowackich.

100 Teoretyczne podstawy prawa ochrony przyrody, pod red. W. Radeckiego, Wrocław 2006.

101 Podstawy teoretyczne zintegrowanej ochrony prawnej środowiska, pod red. W. Radeckiego, Wrocław 2010.

${ }_{102}$ Instytucje prawa ochrony środowiska. Geneza, rozwój, perspektywy, pod red. W. Radeckiego, Warszawa 2010.

103 Organizacja władz publicznych $w$ Polsce, Czechach i Stowacji w zakresie ochrony środowiska a członkostwo $w$ Unii Europejskiej, pod red. J. Sommera, Wrocław 2004; Wybrane problemy prawa ochrony środowiska. Rola sądów. Prawo wodne, pod red. H. Lisickiej, Wrocław 2007; Udział społeczeństwa $w$ zintegrowanej ochronie środowiska, pod red. H. Lisickiej, Wrocław 2010; Konflikty środowiskowe i sposoby ich rozstrzygania, pod red. H. Lisickiej i A. Lisowskiej, Wrocław 2012; Prawna regulacja geologii i górnictwa $w$ Polsce, Czechach i na Słowacji. Wybrane zagadnienia, pod red. G. Dobrowolskiego i G. Radeckiego, Katowice 2014. 
Najmłodszą instytucją naukową jest powstałe w 1999 r. wrocławskie Centrum Prawa Ekologicznego, którego trzon stanowią Magdalena Bar oraz dwaj sommerowcy: Jerzy Jendrośka i Jan Jerzmański. Centrum zapisało się najpierw trzema komentarzami $^{104}$, następnie obszernym podręcznikiem ${ }^{105}$ zbudowanym wedle trójczłonowej koncepcji: prawo międzynarodowe, prawo unijne, prawo polskie, wreszcie zgrabnie ujętym leksykonem ${ }^{106}$. Autorzy z Centrum oraz kilku innych ośrodków naukowych przygotowali duży komentarz do ustawy - Prawo ochrony środowiska ${ }^{107}$. Organizacją prac nad komentarzami zajmowała się Magdalena Bar i jej wzorcowej staranności, sumienności i rzetelności, a także jej nadzwyczajnemu urokowi osobistemu zawdzięczamy to, że udało się o czasie poskładać teksty autorów rozrzuconych po kraju.

Magdalena Bar jest autorką arcyciekawego komentarza do Protokołu EKG ONZ w sprawie odpowiedzialności za skutki awarii przemysłowych na wodach transgranicznych ${ }^{108}$. Zasługą Jerzego Jendrośki jest podjęcie badań nad ocenami oddziaływania na środowisko ${ }^{109}$, których kontynuowanie doprowadziło go do pozycji eksperta w skali nie tylko polskiej i nie tylko europejskiej. Prowadzone przez Jana Jerzmańskiego wnikliwe analizy regulacji dotyczących odpadów, w tym komunalnych (krótko

104 Ustawa - Prawo ochrony środowiska. Komentarz, pod red. J. Jendrośki; Ustawa z 27 kwietnia 2001 r. o odpadach. Komentarz, pod red. J. Jerzmańskiego, Wrocław 2002; Ustawa o opakowaniach oraz o opłacie produktowej i depozytowej. Komentarz, pod red. J. Jendrośki i M. Bar, Wrocław 2002.

105 M. Bar, J. Jendrośka, Prawo ochrony środowiska. Podręcznik, Wrocław 2005.

106 M. Bar, Z. Bukowski, J. Jendrośka, J. Jerzmański, S. Urban, Leksykon prawa ochrony środowiska, Warszawa 2012.

107 M. Górski, M. Pchałek, W. Radecki, J. Jerzmański, M. Bar, S. Urban, J. Jendrośka, Prawo ochrony środowiska. Komentarz, Warszawa 2011, wydanie 2 - Warszawa 2014.

108 M. Bar, Protokół EKG ONZ w sprawie odpowiedzialności cywilnej i odszkodowania za szkody wynikłe z transgranicznych skutków awarii przemysłowych na wodach transgranicznych, Wrocław 2003.

109 J. Jendrośka, Ocena oddziaływania na środowisko (OOŚ). Fachowa ekspertyza czy procedura z udziałem społeczeństwa. Sytuacja w Polsce na tle tendencji światowych, Wrocław 1997. 
mówiąc - śmieci) wraz z odrębnym komentarzem do ustawy o międzynarodowym przemieszczaniu odpadów ${ }^{110} \mathrm{~W}$ pełni usprawiedliwiają nadanie mu zaszczytnego miana „pierwszego śmieciarza Rzeczypospolitej”.

Przez Opole jedynie przemkniemy, doceniając talenty naukowe i organizacyjne Marty Woźniak z Uniwersytetu Opolskiego i zatrzymując się nad materiałami ze znaczącej, współorganizowanej przez ten uniwersytet konferencji w Kamieniu Śląskim w 2007 r., podsumowującej z perspektywy prawa ochrony środowiska trzylecie Polski w Unii Europejskiej ${ }^{111}$.

Podążamy na Uniwersytet Śląski w Katowicach, gdzie spotkamy się z Genowefą Grabowską, autorką monografii poświęconej europejskiemu prawu ochrony środowiska ${ }^{112}$. Uniwersytet Śląski to przede wszystkim wyborny tandem: Aleksander Lipiński i Ryszard Mikosz. Pierwszy z nich to autor kilkakrotnie wznawianego podręcznika prawa ochrony środowiska ${ }^{113}$, cennych opracowań z zakresu prawa geologicznego i górniczego ${ }^{114}$, a monografia drugiego poświęcona odpowiedzialności za tzw. szkody górnicze ${ }^{115}$ może uchodzić za wzór, jak poważne prace naukowe pisać należy. W duecie stworzyli komentarz do prawa geologicznego i górniczego z 1994 r. ${ }^{116}$ (mamy nadzieję, że w nieodległej przyszłości pojawi się ich komentarz do prawa obowiązującego z 2011 r.) oraz opracowanie poświęcone prawnej ochronie śro-

110 J. Jerzmański, W. Radecki, Ustawa o międzynarodowym przemieszczaniu odpadów. Komentarz, Warszawa 2014.

111 Wspólnotowe prawo ochrony środowiska i jego implementacja $w$ Polsce trzy lata po akcesji, pod red. J. Jendrośki i M. Bar, Wrocław 2008.

112 G. Grabowska, Europejskie prawo środowiska, Warszawa 2001.

113 A. Lipiński, Elementy prawa ochrony środowiska, Kraków 2001, a potem Prawne podstawy ochrony środowiska, trzy wydania w Krakowie w latach 2002, 2004 i 2005, dwa kolejne w Warszawie w latach 2007 i 2010.

114 A. Lipiński, Prawo geologiczne i górnicze, Katowice 1996; Użytkowanie górnicze, Kraków 1996; Wprowadzenie do prawa geologicznego i górniczego, Bytom 2003.

115 R. Mikosz, Odpowiedzialność za szkody wyrządzone ruchem zakładu górniczego, Kraków 2006.

116 A. Lipiński, R. Mikosz, Komentarz do ustawy prawo geologiczne i górnicze, wydanie I - Warszawa 1995, wydanie II zmienione - Warszawa 2003. 
dowiska w górnictwie ${ }^{117}$. Obok nich dorastał Grzegorz Dobrowolski, który jako jeden z nielicznych odważył się zmierzyć z tak trudnym zagadnieniem, jakim jest ochrona powietrza ${ }^{118}$, a po napisaniu dzieła o europejskim prawie ochrony środowiska ${ }^{119}$ podjął badania nad decyzją o środowiskowych uwarunkowaniach $^{120}$. Zapewne podczas kilkuletniego obcowania ta decyzja tak mu dokuczyła, że w końcowej części swej monografii złożył (uzasadniony zresztą) wniosek o jej usunięcie z polskiego systemu prawnego. Doceniam wkład Gabriela Radeckiego (zbieżność nazwisk przypadkowa), który wraz z Ryszardem Mikoszem napisał interesujące opracowanie poświęcone opłatom i karom $\mathrm{w}$ ochronie środowiska ${ }^{121}$. Także w artykułach najmłodszej z grupy katowickiej, obdarzonej zniewalającym wdziękiem, powabem i czarem Darii Daneckiej, o źródłach prawa ochrony środowiska ${ }^{122}$ wiele oryginalnych, nieschematycznych myśli znaleźć można. Wstąpmy jeszcze na kwadrans do Tomasza Pietrzykowskiego, niestrudzonego obrońcy zwierząt ${ }^{123}$.

Chciałoby się w Katowicach pozostać dłużej, ale pora się żegnać i ruszać do Krakowa, gdzie wszystko się zaczęło: nauka prawa ochrony przyrody za sprawą Jana Gwalberta Pawlikowskiego i nauka prawa ochrony środowiska za sprawą Wacława Brzezińskiego. Ich dzieło na Uniwersytecie Jagiellońskim kontynuuje z sukcesami Andrzej Wasilewski ${ }^{124}$. W Krakowie powstała

117 A. Lipiński, R. Mikosz, Instrumenty ochrony środowiska $w$ nowym prawie geologicznym i górniczym, Katowice 1995.

118 G. Dobrowolski, Ochrona powietrza. Zagadnienia administracyjnoprawne, Kraków 2000.

119 G. Dobrowolski, Europejskie prawo ochrony środowiska, Katowice 2006.

120 G. Dobrowolski, Decyzja o środowiskowych uwarunkowaniach, Toruń 2011.

121 R. Mikosz, G. Radecki, Leksykon opłat i kar pieniężnych związanych z korzystaniem ze środowiska, Wrocław 2010.

122 D. Danecka, Konstytucyjny katalog źródeł prawa a źródła prawa ochrony środowiska. część I - „Casus” jesień 2012, część II - „Casus” zima 2012.

123 T. Pietrzykowski, Spór o prawa zwierząt. Etyczne problemy prawa, Katowice 2007.

124 A. Wasilewski, „Ochrona środowiska” jako kryterium ocen prawnych, „Krakowskie Studia Prawnicze” 1986, Rocznik XVI; Prawna problematyka ochrony środowiska $w$ związku z przystapieniem Polski do Unii Europejskiej 
skromna objętościowo, ale niezwykle ciekawa książka Izabeli Dobosz, Stefana Grzybowskiego i Anny Wojciechowskiej poświęcona środowisku jako dobru intelektualnemu ${ }^{125}$. Nie można jednak zaprzeczyć, że w ostatnich latach dał się zaobserwować pewien zastój krakowskiej nauki prawa ochrony środowiska, aż wreszcie z 2013 r. nastąpiło prawdziwe wejście smoka w postaci skargi zbiorowej w ochronie środowiska Barbary Iwańskiej ${ }^{126}$. Oczywiście, nigdy bym sobie nie pozwolił na zestawienie subtelnej urody Barbary Iwańskiej z aparycją smoka, ale mam na uwadze nie autorkę, lecz jej dzieło, w którym na 700 z górą stronach znajdujemy wszystko, co można powiedzieć o środowisku jako dobru wspólnym, podbudowane wyśmienitą, starannie udokumentowaną i w pełni przekonywającą analizą egoistycznej i altruistycznej ochrony środowiska. Przed opuszczeniem Krakowa wpadnijmy jeszcze na chwilę do redakcji „Aury”, aby pogratulować Edwardowi Garści, redaktorowi naczelnemu tego miesięcznika, ponad czterdziestu lat ukazywania się periodyku poświęconego w całości ochronie środowiska. „Aura” nie jest wprawdzie czasopismem prawniczym, ale i prawnicy często goszczą na jej łamach, że wymienię choćby Adama Habudę prowadzącego od trzech lat stały cykl poświęcony orzecznictwu Trybunału Sprawiedliwości Unii Europejskiej w sprawach ochrony środowiska.

Żegnamy Kraków i udajemy się na Uniwersytet Rzeszowski, gdzie przyjmuje nas przesympatyczna Elżbieta Ura, która wraz ze Stanisławem Pieprznym i współpracującym z nimi Jerzym Stelmasiakiem (poznaliśmy go bliżej, kiedy byliśmy w Lublinie) zorganizowała dwie znaczące konferencje, z których materia$ł^{127}$ istotnie wzbogaciły polską naukę prawa ochrony środo-

(kwestia granic związania Państw Członkowskich prawem WE), „Kwartalnik Prawa Publicznego" 2007, nr 2.

125 I. Dobosz, S. Grzybowski, A. Wojciechowska, Zagadnienia ochrony środowiska jako dobra intelektualnego, Warszawa-Kraków 1989.

126 B. Iwańska, Koncepcja „skargi zbiorowej” w prawie ochrony środowiska, Warszawa 2013.

127 E. Ura, J. Stelmasiak, S. Pieprzny (red.), Człowiek a środowisko. Aspekty prawno-społeczne, Rzeszów 2010; Ocena modelu prawnego organizacji ochrony środowiska $w$ Polsce i na Stowacji, Rzeszów 2012. 
wiska. Z Rzeszowem kojarzy nam się także Adam Erechemla, pomysłodawca i redaktor cennego zbioru studiów z dziedziny ochrony środowiska ${ }^{128}$. Adam Erechemla czuwa u Jacka Zyśka nad tym, aby czytelnicy „Prawa i Środowiska” zawsze mieli aktualne informacje o tym, co w ochronie środowiska dzieje się w Unii Europejskiej.

\section{KILKA REFLEKSJI KOŃCOWYCH}

Na trasie od Szczecina do Rzeszowa odwiedziliśmy najważniejsze ośrodki naukowe zajmujące się prawem ochrony środowiska. Nie mam zamiaru proponować ich rankingu, gdyż trzeba byłoby uwzględnić zbyt wiele kryteriów. Ale o zastosowanie jednego kryterium aż się prosi: dysponowanie własnym $\mathrm{w}$ miarę aktualnym podręcznikiem prawa ochrony środowiska lub dziełem swym charakterem do podręcznika zbliżonym. Podręcznikiem „W miarę" aktualnym może być napisany po 1 maja 2004 r., tj. po wstąpieniu Polski do Unii Europejskiej i dopełnieniu wielkiej reformy prawa środowiska roku 2001 (Prawo ochrony środowiska, Prawo wodne, ustawa o odpadach) ustawą o ochronie przyrody. Takie kryterium spełniają: Gdańsk, Olsztyn, Toruń, Łódź, Lublin, Wrocław (wszystkie trzy ośrodki wrocławskie) i Katowice. Ale jeżeli zaostrzymy kryterium, mając na uwadze, że ustawa o odpadach z 2001 r. została zastąpiona nową z 2012 r., to kryterium spełni już tylko Łódź, a jeżeli jeszcze je zaostrzymy, domagając się uwzględnienia w pełni aktualnego stanu prawnego, to tak zaostrzonego kryterium nie spełnia żaden ośrodek naukowy, bo nawet podręcznik „łódzki” z 2014 r. nie uwzględnia noweli Prawa ochrony środowiska z lipca 2014 r. To jest największa trudność stojąca przed przedstawicielami nauki prawa ochrony środowiska: dotrzymanie tempa zmianom legislacyjnym $\mathrm{w}$ tej dziedzinie prawa; nikt go nie dotrzymuje, bo dotrzymać nie jest w stanie.

128 Prawo dla środowiska, pod red. A. Erechemli, Rzeszów 2011. 
Jak przedstawia się dorobek naukowy w dziedzinie prawa ochrony środowiska? Od kilkunastu lat prowadzę własną „buchalterię" wydawnictw, ale tylko książkowych. Doliczyłem się około 450 pozycji poświęconych prawu ochrony środowiska w szerokim rozumieniu, uwzględniającym, co oczywiste, prawo ochrony przyrody. Zapewne nie dotarłem do wszystkich, ale chyba do zdecydowanej większości, można przeto liczyć, że dorobek naukowy wynosi co najmniej pół tysiąca tytułów książek o prawie ochrony środowiska. Studiów, artykułów i glos do orzeczeń sądowych nikt nawet nie próbował policzyć i nie policzy, byłoby to bowiem zadanie niewykonalne. Można szacować, że nawet gdyby odliczyć kilkustronicowe „drobiazgi”, liczba artykułów poświęconych prawu ochrony środowiska idzie $\mathrm{w}$ tysiące. Istnieją wprawdzie tylko trzy periodyki poświęcone wyłącznie tej dziedzinie prawa: toruński „Przegląd Prawa Ochrony Środowiska”, piaseczyńskie „Prawo i Środowisko” i wrocławska „Ochrona Środowiska. Prawo i polityka” (do tego dochodzi jeszcze toruński „Polish Yearbook of Environmental Law"), ale studia, artykuły i glosy z zakresu prawa ochrony środowiska ukazują się także w „klasycznych” czasopismach prawniczych, w wydawnictwach uniwersyteckich i innych periodykach.

Spośród publikacji książkowych chciałbym kilka słów poświęcić komentarzom jako opracowaniom szczególnie poszukiwanym przez praktyków stykających się z zagadnieniami ochrony środowiska. Ograniczając się do dziś obowiązujących najważniejszych ustaw z tej dziedziny, zauważmy, że ustawa Prawo ochrony środowiska doczekała się sześciu komentarzy różnych autorów bądź zespołów autorskich, ustawa Prawo wodne - czterech, ustawa Prawo łowieckie - czterech, ustawa o odpadach - trzech, ustawa o ochronie przyrody - dwóch, ustawa o lasach - dwóch, ustawa o szkodach w środowisku - dwóch, ustawa o ocenach oddziaływania na środowisko - dwóch. Niektóre z tych komentarzy kilkakrotnie wznawiano „W rytm” zmian w komentowanych ustawach.

Nieźle przestawia się w literaturze polskiej międzynarodowa i unijna problematyka ochrony środowiska, a także prezentacja rozwiązań przyjmowanych $\mathrm{w}$ innych państwach, przede 
wszystkim czeskich i słowackich, ale także niemieckich, austriackich, włoskich czy ukraińskich.

Ocena stanu polskiej nauki o prawnej ochronie środowiska nie wypada źle, dorobek piśmienniczy jest duży i urozmaicony, liczba pracowników naukowych zajmujących się tą dziedziną znaczna, a naturalna wymiana pokoleń i napływ młodych ludzi do naszej dyscypliny naukowej pozwala z ostrożną ufnością spoglądać w przyszłość. 